\title{
Researchers find silver lining in delay to work on space station
}

[WASHINGTON] An announcement last week by the US National Aeronautics and Space Administration (NASA) of a delay of up to 11 months in construction of the International Space Station may have angered the project's supporters in Congress. But it is good news for scientists, as the agency plans to fly additional research missions on the space shuttle now that it will not be tied up delivering pieces of the station to orbit.

The delay is needed to provide time for a key Russian module to be completed. The Russian government has promised that money will be forthcoming to complete the service module, which will maintain the station in orbit and house its initial crew.
But NASA managers say they will not know until next month whether the Russians can keep the promise.

As a hedge against this problem, NASA has decided to let the date of the first construction flight slip from November 1997 to no later than October 1998. If Russia defaults, the United States would have to build its own 'interim control module' to keep the station in the proper orbit during the early stages of assembly.

Even before the slip in the schedule, NASA had been looking for ways to placate scientists who have become increasingly frustrated with the lack of flight opportunities for their orbital experiments in the near future. To pay for cost overruns in building the station itself, the agency has had to defer development of some of the science equipment it is planned to carry.

Facilities once planned to be available for use by researchers in 1998 have now slipped to 2000 or later. At the same time, NASA has cut the number of remaining shuttle/Spacelab research flights to two - a multidisciplinary Microgravity Science Laboratory (MSL) which flew last week, and the Neurolab mission devoted to neurological research, which will carry an international payload in collaboration with the US National Institutes of Health next March.

This squeeze meant that researchers who depend on data from space experiments faced a long 'dry' spell, according to Martin Glicksman, a materials scientist at Rensselaer Polytechnic Institute in Troy, New York, and chair of a National Research Council committee that oversees NASA's microgravity research. He says that some disciplines were looking at a hiatus of nearly four years without experimental data. "People cannot be asked to stand in a queue that long."

Last week's premature landing of the MSL Spacelab mission - due to a failed electrical fuel cell - made matters worse. Astronauts were scheduled to spend 16 days in orbit, conducting 33 life science and materials science experiments and testing experimental hardware to be used on the space station. Instead, they came home after only four days, completing what little work they could by flashlight to conserve electricity.

NASA immediately announced plans to refly the MSL mission in July with the same experiments and crew. And now that the shuttle's short-term schedule has been freed by the station delay, the agency is considering additional flights in 1998 and 1999 devoted to research in life sciences, materials science and commercial product development.

Joel Kearns of the Marshall Space Flight Center in Alabama, who directs NASA's microgravity research programme, says the extra flights could either be reflights of existing MSL and Neurolab equipment, or newly developed equipment, which could fly either in Spacelab or in the privately leased Spacehab module. The agency hopes to fly some of the experiments it has already selected for the early station years on these shuttle flights instead.

The number of missions to be added, and how they will be financed, still has to be worked out between NASA, the White House and Congress. Money is scarce, particularly since the agency is asking 